Jpn. J. Med. Mycol.

Vol. 27, 75-81, 1986

ISSN $0583-0516$

\title{
Opportunistic Fungus Infections
}

\author{
一内科領域一
}

\author{
渡 辺 一 功 \\ (順天堂大学医学部内科・感染症)
}

真菌症，ことに深在性真菌症は日和見感染（opportunistic infection）として最も早くから注目されて 扣り, 種々の immunocompromised hostへの合併症として, また終末感染症として本邦でも欧米でも増 加傾向が指摘されている. 本邦では 1950 年頃を境に急激に報告例が増加している.これはペニシリンを はじめとする種々の抗生剂, 副腎皮質ホルモン, 抗腫瘍剤の普及とも時期が一致している.

内科領域で opportunistic fungus infection を早期に診断することは極めて困難であり, 剖検により確 定診断される症例が多いことを認めざるをえない，臨床の実体が明らかになるにつれ，生前に診断され る症例も次第に増加してきているが, 早期に診断可能で治療の対象となる疾患はカンジダ血症, 食道カ ンジダ症, クリプトコックス髄膜炎など僅かであり, 全身播種型のカンジダ症, アスペルギルス症, ク リプトコックス症, ムーコル症などは剖検により診断される場合が多い。

今回のシンポジゥムにあたり, 我々の教室で経験したカンジダ症, アスペルギルス症, クリプトコッ クス症, ムーコル症扣よびノカルジア症の日和見感染症例を提示し，その現状を報告した.

Key words：日和見感染（opportunistic infection), 深在性真菌症 (deep-seated mycosis)

近年, 真菌症ことに深在性真菌症は日和見感染 （opportunistic infection）の代表的な疾患として注目 をあびていることは周知のと扔りである。

広域抗生剂, 抗腫瘍剂, 副腎皮質ホルモン, 免疫抑 制剂などの沉用，ぬた近年の急速な医療技術の進歩に 伴い生体防御能の低下した易感染性の宿主（immunocompromised host）が増加してきて拉り，これ らの宿主に対して合併症として, あるいは終末感染症 としての深在性真菌症が増加傾向にあることは本邦で も，また欧米でも同様である。これは原発性真菌症の 増加もあろらが, 続発性真菌症, とりわけ深在性真菌 症の増加によるものである。

本邦でも神田ら ${ }^{1)} 1958$ 1969 年の 12 年間の日本 病理剖検輯報の集計では剖検総数 203,964 例中 2,454 例, $1.4 \%$ に真菌感染を認めている.

奥平ら 2 の $1972 \sim 1981$ 年の 10 年間の同様の集計で は, 剖検総数 280,532 例中 7,049 例， $2.51 \%$ 真菌感 染を認め, かつ遂年的に増加傾向があり，敗血症を含

\footnotetext{
別刷請求先：渡辺一功

于 113 東京都文京区本郷 $2-1-1$

順天堂大学医学部内科学教室
}

む多藏器への罹患症例が増加し，とくに直接死因とな る症例の発現頻度が経年的に増加の傾向を示し, とく に 1976 年以後のカンジダ症の増加とともに重篤例の 増加が指摘されている。

しかし，内科領域から日和見感染としての真菌症を 診断, 治療することは甚だ困難であるといわざるを党 ないのが現状であり,さらに副作用が少なく, かつ有 効な抗真菌剂を入手することが困難であるため, 益々 近年の増加傾向に拍車をかけている.

現在, 我々内科領域に扔いて早期に診断可能で, か つ治療の対象となりらる疾患としてはカンジダ血症, 食道カンジダ症, クリプトコックス髄膜炎など少数で あり, 組織侵襲型の肺アスペルギルス症, 肺カンジダ 症，ムーコル症などはその臨床診断が困難であるため 治療の対象とならず，剖検にて診断される場合が大多 数である.

以下, 我々の教室で経験した症例を提示し, 内科領 域からみた現状について報告する。

\section{1. カンジダ症}

本症は Candida albicans をはじめとするCandida 属の諸種によりおこる急性または慢性の表在性, 深在 
Table 1. Annual incidence of candidemia at Juntendo University Hospital, 1972 1983

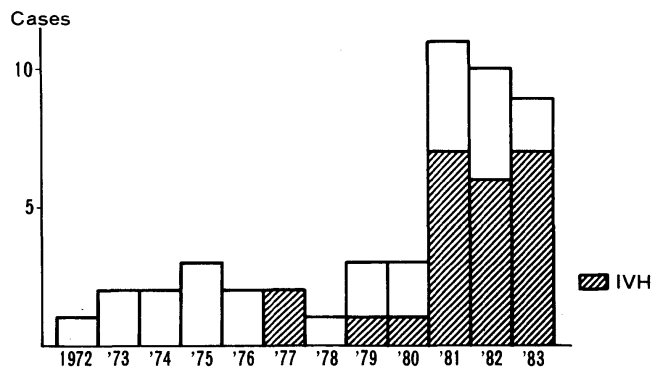

性または播種性の真菌症で，病像はきわめて多彩であ る. 口腔, 食道, 気管支, 肺, 腔, 皮膚などが侵され, ときに真菌血症, 心内膜炎, 髄膜炎を扣こし, 重篤な 場合には全身性に播種し小膿瘍（腎，心筋，脳，肺な ぞ)を形成することが特徵的である．奥平ら²) 指摘す るように近年増加傾向があり，広域抗生剂などの投与 をらけている免疫不全者では常に深在性カンジダ症を 考慮する必要があり, 粘膜病変のみでも注意が必要で ある。

肺カンジダ症は経気管支性,一部は血行性に発症し， 肺炎ないし肺膿瘍をきたすが，細菌との混合感染も多 く, 燕下性肺炎の色彩が濃いが3), カンジダ血症やカン ジダ心内膜炎に随伴することが多い. 確定診断は肺生 検以外にはなく，血清学的診断法の開発は目覚しいも のがあるが，末だ信頼性に乏しい，我々にも生前に診 断しえた症例の経験はない.

深在性カンジダ症のなかで，最近とくに注目されて いるものにカンジダ血症があり, 近年増加傾向にある. Table 1 は我々の施設で経験したカンジダ血症の年次 的推移を示すが, 1981 年より増加傾向が認められる. 69 例中 24 例に高カロリ一栄養 (IVH) が施行されて拉 り, 1981 年以後の 3 年間では 30 例中 20 例, $66.7 \%$ に IVH が関与していることが分る. カンジダ血症は悪性 腫瘍や白血病に合併することがしられていたが，近年 はIVH が関与することが多く，これ以外にも静脈内 カテーテル留置時などに発症しやすい. Table 2 は分 離されたカンジダ属を示すが，C. albicans 执よびそれ 以外の種が相半ばしている. Table 3 はこれらの症例 の基礎疾患を示すが，胃癌をはじめとする悪性腫痬が 多く, これらの症例に対して今日 IVH が沉用されて いる事実を反映している。Table 4 は IVH 開始と発 症の関係を示したものであるが, IVH 関始後 3 週以後 の症例に多く, 悪性腫瘍を基磯疾患として IVHを施
Table 2. Isolated Candida species from candidemia

\begin{tabular}{lc}
\hline C. albicans & 23 \\
C. tropicalis & 9 \\
C. parapsilosis & 7 \\
C. guilliermondi & 3 \\
C. stellatoidea & 1 \\
Candida sp. & 6 \\
\hline \multicolumn{1}{c}{ Total } & 49 \\
\hline
\end{tabular}

Table 3. Underlying disease of candidemia

\begin{tabular}{llll}
\hline Carcinoma & & & \\
\hline Stomach & 8 & Rhabdomyosarcoma & 1 \\
Esophagus & 3 & Liponeurosarcoma & 1 \\
Liver & 3 & Malignant xanthofibroma & 1 \\
Intestine & 2 & Malignant lymphoma & 1 \\
Pancreas & 2 & Neuroblastoma & 1 \\
Lung & 1 & & \\
Duodenum & 1 & & \\
Ovary & 1 & & \\
\hline
\end{tabular}

Pneumonia(4), cerebral embolism(4), angina pectoris (Ope.) (4), parkinsonism(2), subdural hydrops(2), congenital heart disease(Ope.) (2), aneurysm(2), lleus (2), renal failure(2), lung abscess(1), alcoholisms(1), colitis ulcerosa(Ope.)(1), liver cirrhosis(1), diabetes mellitus(1), microcephalus(1), fulminant hepatitis(1), rheumatoid arthritis(1), pancreatitis(1), Crohn's disease(1), cholelithiasis(1), congenital intestinal obstruction(1), Ritter's disease(1), congenital bile duct atresia(1), malposition of intestine(1)

Table 4. Episodes of candidemia by week of initiation in patients with IVH

\begin{tabular}{rl}
\hline$>1 \mathrm{~W}$ & 0 \\
$2 \mathrm{~W}$ & 3 \\
$3 \mathrm{~W}$ & 7 \\
$4 \mathrm{~W}$ & 4 \\
$4 \mathrm{~W}>$ & 8 \\
\hline
\end{tabular}

行した症例で 3 週以後に発熱, 悪寒を認めた場合には カンジダ血症への配慮が必要である。

カンジダ血症は注射液の污染, フィルターの污染, 皮膚静脈瘻での真菌の増殖, 流血中の Candida の力 テーテル尖端への定着などに起因するが，一過性のカ ンジダ血症のこともあり, この際はカテーテルの拔去 
Table 5. Cryptococcal meningitis at Juntendo University Hospital, 1957-1985

\begin{tabular}{ccclc}
\hline Case & Age & Sex & \multicolumn{1}{c}{ Underlying disease } & Results \\
\hline 1 & 62 & M & Liver cirrhosis & Died \\
2 & 43 & M & None & Died \\
3 & 19 & M & Nephrosis & Died \\
4 & 64 & M & Liver cirrhosis & Cured \\
5 & 63 & F & None & Cured \\
6 & 27 & F & S.L.E. & Cured \\
7 & 53 & F & Diabetes mellitus & Cured \\
8 & 55 & M & Diabetes mellitus & Died \\
9 & 62 & M & Malignant lymphoma & Died \\
10 & 74 & M & Hypersensitivity pneumonitis & Died \\
11 & 36 & F & S.L.E. & Cured \\
\hline
\end{tabular}

Juntendo University

のみで自然治癒する場合もあるが，放置すれば播種性 カンジダ症となり重篤な状態をきたす。播種性カンジ ダ症では心筇炎 ${ }^{5)}$, 脳炎(6)の発生率が高く，いずれも多 発性小膿崵を形成する。

内眼球炎 (眼内炎) (endophthalmitis) は播種性カン ジダ症の早期発見に重要な所見であり7)，脈絡網膜炎 の渗出物が硝子体にでて, 多数の白い綿球状浮遊物 (cotton ball like lesion) が観察されるので（Fig. 1)， とくに大量の抗生剂や血管カテーテル留置例で発熱を 認めた場合には眼底検查が必要である。あた血行性皮 膚病変として斑状小結節状病変を認めることがあり，

このような場合は生検で Candida を認めることがあ る. カンジダ心内膜炎は麻薬中毒者や弁置換後に久ら れることがあるが，幸い本邦では少ない。

血液疾患に合併することが多く，近年増加傾向にあ る食道カンジダ症には食道造影括よび食道内視鏡が有 用であり，食道造影では粘膜の結節状欠損像，不規則 像が特徵的であり ${ }^{8)}$, 食道内視鏡では粘膜面がクリー ム状の白苔の偽膜で被われているのがみられる。しか し, 食道造影で異常を認めない場合もあり, 内視鏡検 査が最も有用であるとするものもいる ${ }^{9,10)}$. 我々も屡々 食道カンジダ症を経験しているが，早期診断を心がけ るとともに ketoconazole の投与により良好な治療成 績を壳ている ${ }^{11}$.

\section{2. アスペルギルス症}

本症は Aspergillus 属のいくつかの種によりおこる 疾患であり, 膿瘍, 肉芽腫などの感染型(組織侵襲型), 菌球で代表される定着型扣よびアレルギー型の三つに

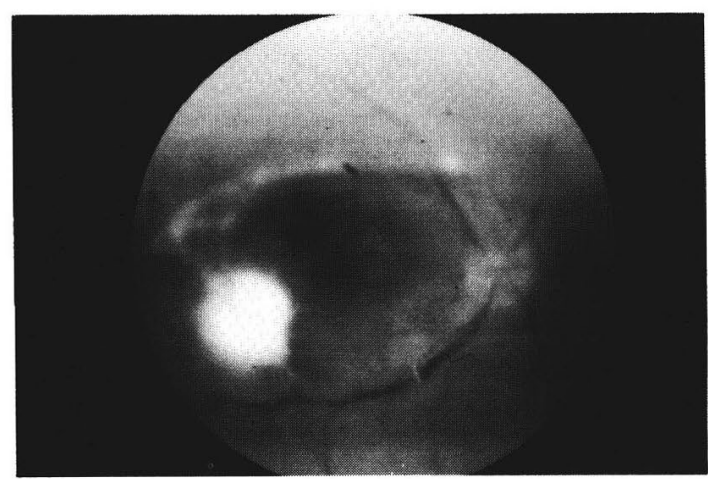

Fig. 1. Fundus photogrph of Candida endophthalmitis, showing a cotton-like lesion.

大別されるが，感染型のアスペルギルス症招よび近年 Binder ら ${ }^{12)}$ により提唱されている慢性壊死性肺アス ペルギルス症が日和見感染症として最も重要であり, 肺病変が最も多く,重篤なものでは全身性に播種する。

アスペルギルス肺炎・肺膿瘍は組織侵襲型の代表的 なもので，急性白血病や臓器移植に合併することが多 く ${ }^{13)}$, 末梢成熟好中球が $500 / \mu 1$ 以下になると発病の頻 度が高く, 無治療の場合には発病後約 2 週間で死亡す るといわれ，重篤な基礎疾患をもつものの終末感染の 色彩が深い。この組織侵襲型の臨床症状は不定で, 臨 床診断は一般に極めて困難であり, 血清学的診断も確 立されていない。発熱と胸部異常陰影を呈する程度で あり, 肺梗塞をきたすと胸痛, 血痰, 喀血を認めるが, 胸部X線像で梗塞像を認めても疑いはもてるが，これ のみでは診断不能である。確定診断は生検によらざる をえないが，実際には生検は敢行しがたく，臨床的綜 合判断のほかに喀痰の塗抹染色標本に上るAspergillus 菌糸の発見，または培養検査などによることが多 い. Fig. 2 は 63 歳, 男性の赤白血病に合併したAspergillus による肺梗塞症例の喀痰塗抹標本であるが, Aspergillus と思われる隔壁をもつ菌系が多数みられ る．肺アスペルギロームの場合より発見する頻度が高 いため疑いのある症例では頻回に試みる努力が必要で ある。また 54 歳，男性の急性骨髄性白血病患者の喀痰 よりAspergillus が分離されながら剖検では両肺にう つ血像を認めるのみで真菌による病変はなく, 気管に 小豆大のゼラチン様のポリープ様病変と潰瘍を認め, Aspergillus が粘膜下に侵入発育していた稀な症例 ${ }^{14)}$ も経験して抢り，今後はこのような症例にも注意する 必要がある。また 57 歳, 男性の肺アスペルギロームの 


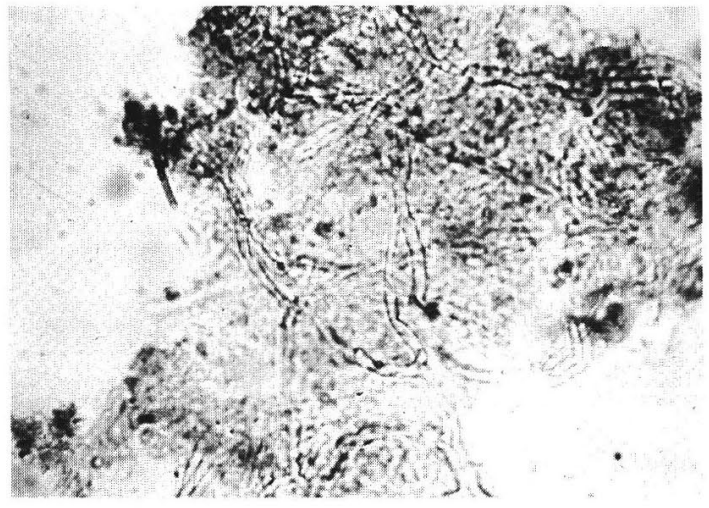

Fig. 2. Fungal elements in expectorated sputum.

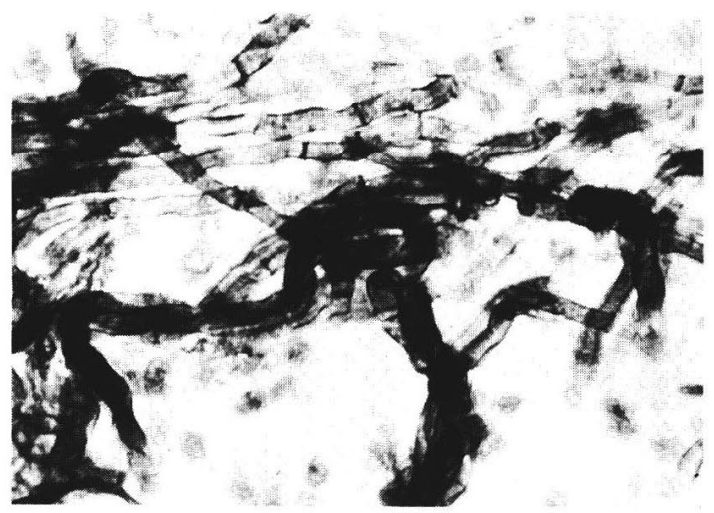

Fig. 3. Fungal elements in pleural effusion.

治療中に気管支胸膜瘻発生によるものと思われるアス ペルギルス胸膜炎の症例も経験している。この症例で は Eikenella corodens, Bacteroides melaninogenicus などの嫌気性菌とともに A. fumigatus を胸水より分 離し, miconazole の胸腔内注入で治癒している. Fig. 3 はこの症例の胸水中の A. fumigatus を示す.

播種型ではほとんどの臓器が侵され，多発性小膿瘍 が特徴とされているが，診断は極めて困難であり生検 以外に方法はない。

\section{3.クリプトコックス症}

本症は Cryptococcus neoformans に上る慢性，亜急 性，稀に急性の肺，脳，髄膜あるいは全身性の感染症 であるが，脳髄膜に強い親和性をもつため髄膜脳炎を 主な臨床病型としている. Table 5 はこれ迄に我々の 経験したクリプトコックス䯣膜炎の症例を示す．本症 の基磯疾患は本邦の集計では悪性リンパ腫, SLEが多 く ${ }^{15)}$ ，副腎皮質ホルモン剂の連用がとくに重視されて いる.しかし，約 $1 / 2$ の症例は一見健康人にみられ，

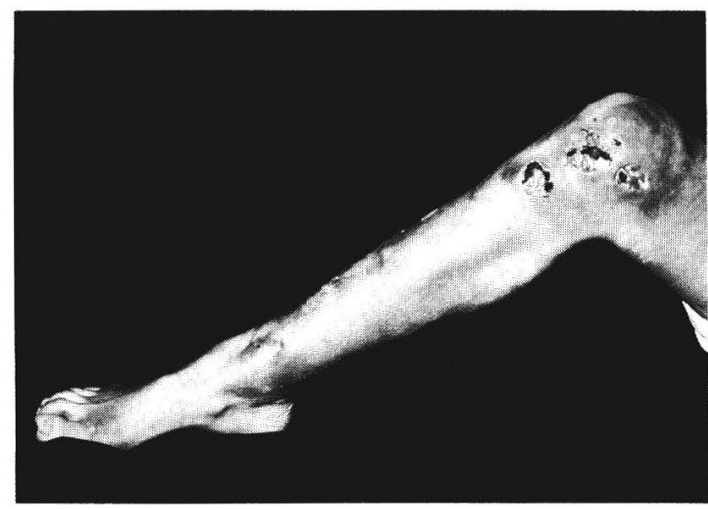

Fig. 4. Cutaneous infection due to Cryptococcus neoformans, superficial ulcers involving mucocutaneous area of right leg.

この点がカンジダ症, アスペルギルス症, ムーコル症 とは著しく異なっている，我々の症例では基礎疾患を もたないものは 2 例のみで, 肝硬变, 糖尿病が各 3 例, SLE 2 例, 悪性リンパ腫, ネフローゼ, 過敏性肺臓炎 各 1 例であった。

本症は比較的に診断が容易であり，近年血液および 髄液中の抗原力価の測定が可能であり，これが診断， 治療, 予後の判定に有用である ${ }^{16,17)}$. しかし, 肺りリプ トコックス症では一般に信頼度が低く, 肺病変のみの 症例では $1 / 3$ に血中に抗原を認めるにすぎないとい $5^{18)}$. 胸膜炎を合併した際の胸水, 播種型の血液では抗 原物質を検出することがあり試みるべきである。

Fig. 4 は 34 歳, 女性の SLEに合併した肺拉よび皮 膚クリプトコックス症の皮膚病変であるが, SLE 治療 中に誘因なく右大腿内側から下腿に軽度隆起する境界 明瞭な紅色局面を認め，その中に鷄卵大迄の潰瘍が多 発し, 一部融合し, 皮卜組織は瘦孔を形成し多量の膿 汁を認めている。Fig. 5 は膿汁の墨汁法による直接鏡 検像で，厚い萊膜をもつC. neoformans が多数みられ る. 血行性播種の約 $5 \%$ に皮膚クリプトコックス症が みられ，痤瘡様発疹が多いとされている。本症例では 肺クリプトコックス症も合併しており, 胸部X線で孤 立円型陰影を認め喀痰の塗抹標本, 培養で C. neoformansを認めている.この他にも SLE末期に合併した 粟粒様陰影をきたした症例も経験しているが生前診断 はできなかった。肺クリプトコックス症には肺結核に 類似した浸潤影を呈することもある.

近年，本邦に拈いても経気管支肺生検により診断さ れる症例も増加してきている。播種型のクリプトコッ 


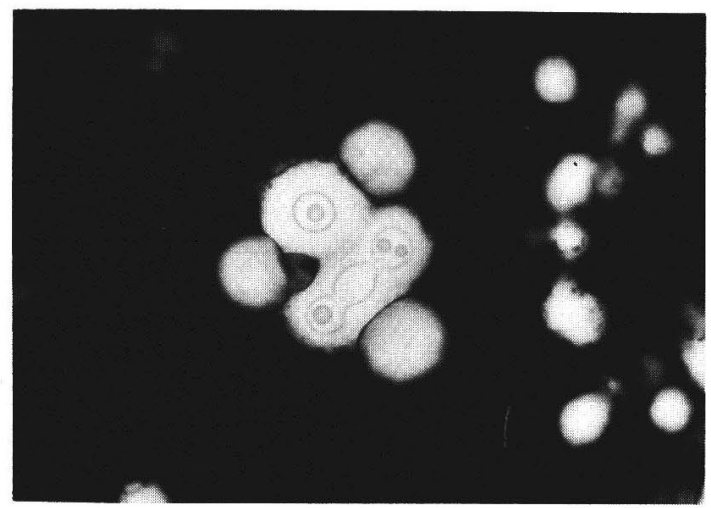

Fig. 5. India ink preparation of pus showing yeast cells surounded by large capsule.

クス症の早期発見には康沈椬中の本真菌発見が役立つ とされている19).

\section{4. ムーコル症}

本症はMucor, Absidia, Rhizopus などの薬菌類 （phycomycetes）による急性電撃性全身感染症で白血 病や重症糖尿病に合併することが多く，発症の様式は アスペルギルス症に類似しているが，発症後の経過が 早く胸部X線所見からアスペルギルス肺资, 肺カンジ ダ症との鑑別は困難であり, 副鼻腔眼窩型の夕が生検, 培養により生前診断が可能であるが，その他の生前診 断は極めて困難である。

本症例の特徵は本菌が血管, とくに動脈に親和性を もち血管を穿通して血检をつくり梗塞をあらゆる臓器 組織に扢こすことである。

血液培養, 喀疢培養もほとんどが陰性であり, 血清 学的診断も信頼しらるものはない。このため確定診断 には生検材料で典型的な幅広い隔壁のない菌系を確認 する必要があるが，アスペルギルス症などと同様に生 検は敢行しがたい，最近，集団検診で発見されたり， 糖尿病に合併した症例で外科的に切除した慢性型の肺 ムーコル症の報告があるが稀なものである ${ }^{21}$.

\section{5. その他}

放線菌症とノカルジア症は原因菌は分類学上細菌に 位置するが，慣習上真菌症として取り扱われている。 汪とんどがActinomyces israelii による慢性化膿性な いし肉芽腫性感染症である。放線菌症は抗細菌化学療 法の普及により近年減少しているが，ノカルジア症は 免疫不全者に対する日和見感染症として注目されてお $\eta^{22)}$, 我々も最近 2 例の肺, カルジア症, 1 例の皮膚, カルジア症を経験している。

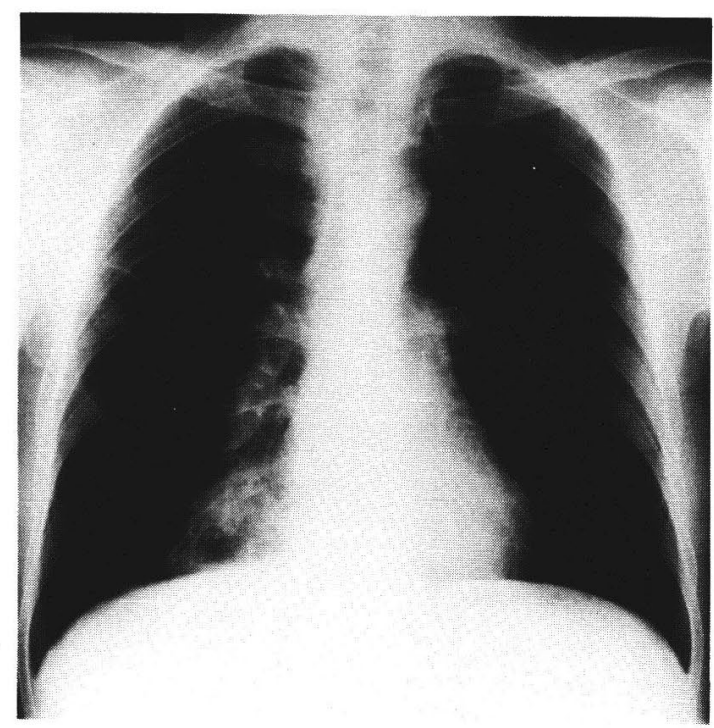

Fig. 6. Chest radiograph of nocardiosis, showing cavitary lesion in the right lower lung.

ノカルジア症は好気性の放線菌類, とくに Nocardia asteroidesによる急性ないし慢性の炎症性疾患であ り, 病理学的には化膿性あるいは肉芽腫性病变を呈す るとされている。臨床的には原発性の皮䖉拉よび皮下 組織の病変と肺病変扰よび全身性播種がある。,カル ジフ症の $75 \%$ は肺に原発するが, 肺病変は小葉性また は大葉性肺炎, 孤立性の肺膿瘍, 急性壊死性肺炎, 栗 粒結核に類似した散布性病変, 肺菌球, 進行性の肺線 維症, さらには放線菌症之同様に穿通による肋膜掞よ び胸壁の病変など多彩であるが，典型例では肺膿瘍の 所見を呈し，多房性空洞がみられる。Fig. 6 は 42 歳, 男性の悪性リンパ腫の治療中 (VEMP 療法)にみられ た肺ノカルジア症の胸部X線正面像であり，右下葉に 多房性空洞がみられる。

診断の約 $40 \%$ が剖検診断によるといわれている が199, 診断は臨床的背影, 臨床像, 胸部X線所見のほか, 喀痰の塗抹, 培養検査により N. asteroides を証明する ことが必要であり, 喀痰のグラム染色では幅 $0.1 \sim 1 \mu$ に分節したフイラメント状細菌が発見される。喀痰培 養でNocardia を証明することは容易ではなく繰り返 し行う必要があり, 通常の細菌培養上り長期間培盖す る必要がある。㐬た肺に病変がなくとも分離されるこ とがあり診断が困難な場合も少なくない。このため気 管支鏡下の病巣擦過, 経気管支肺生検拈上び空洞内吸 引，超音波下の肺生検などで診断を確定しょうとする 
努力がされている．血清学的診断も未だ信頼性にとぼ しい.

本症は確実に奏効する薬剤 (サルファ剂) ST 合剤な ど)があるため診断への努力を拈こたってはならない．

以上のほかに稀には肺にかぎっても肺ゲオトリクム 症, 肺スポロトリコーシス, 肺クラドスポリウム症, 肺ペニシリウム症, 肺ペトリエリジウム症（アレシュ リア症）などの報告がある。 またヒストプラスマ症, コクシジオイデス症, ブラストミセス症, パラコクシ ジオイデス症などがあるが，何れも本邦には定着した 疾患ではないが，今後はこのような感染症が拈こりう る可能性もあり注意すべきであろう。

\section{おわりに}

内科医にとって最も切実な問題は深在性真菌症の診 断と治療である。これ迄は剖検診断によるものが汪と んどであったが，臨床の実体が明らかになるにつれて 生前に診断される症例も次第に増加してきているが， それでも今日な招特殊な病型を除いては臨床診断率が 極めて低いことを認めざるをえないのが現状である。

治療に関しても動物実験や in vitro の段階では有効 な薬剂も少なくないが，現在入手しらる深在性真菌症 に対する薬剤は amphotericin B, flucytosine 抢よび 最近発売されたイミダゾール系抗真菌剤の miconazole があるのみである。

真菌による日和見感染症の治療や予防は抗真菌剤の 開発もさることながら, 宿主の基礎疾患との関連で検 討されねばならず，このためにも宿主の感染抵抗性を 判断するパラメーターの検討や免疫血清学的診断方法 の開発, 宿主抵抗力を増強させる方法の研究など残さ れた課題は多い。

\section{文献}

1）神田実喜男, 盛山眞行, 池田正夫, 小島碩哉, 徳永 正義，渡辺五郎：本邦に抬ける剖検からみた深在 性真菌症, とくにクリプトコッカス症. 臨床病理, $20: 323-329,1972$.

2）木村千恵子, 久米 光, 奥平雅彦：内臟真菌症の統 計学的考察一日本病理剖検輯報から一。第29回日 本医真菌学会総会, 別府, 1985 .

3）渡辺一功：日和見感染と治療一真菌症, 治療学, $13: 505-510,1984$

4) Schiffman, R.L., Johnson, T.S., Weinberger, S. E., Weiss, S.T. and Schwartz, A.: Candida lung abscess: Succesful treatment with amphotericin B and 5-fluorocytosine. Am. Rev. Respir. Dis., 125: 766-768, 1982.

5) Franklin, W., Simon, A.B. and Sodeman, I.M.:
Candida myocarditis without valvulitis. Am. J. Cardiol., 38 : 924-928, 1976.

6) Bayer, A.S., Edwards, J.E., Seidel, J.S. and Guze, L.B.: Candida meningitis: Report of seven cases and review of the English literature. Medicine, 55 : 477-486, 1976.

7) Fishman, K.S., Griffin, J.R., Sapico, F.L. and Hecht, R.: Haematogenous Candida endophthalmitis-A complication of candidemia. New Engl. J. Med., 286 : 675-681, 1972.

8) Trier, J.S. and Bjorkman, D.J.: Esophageal, gastric, and intestinal candidiasis. Am. J. Med., $77: 39-43,1984$.

9) Sherlock, P., Goldstein, M.J. and Eras, P.: Esophageal moniliasis. Med. Treat., : 1250-1260, 1970.

10) Kobayashi, R.H., Rosenblatt, H.M., Garney, J. M., Bryne, W.J., Ament, M.E., Mendoza, G.R., Dudley, J.P. and Stiehm, E.R.: Candida esophagitis and laryngitis in chornic mucocutaneous candidiasis. Pediatrics, $66: 380-$ $384,1980$.

11）森健, 浜本恒男, 日比野順子, 饗庭三代治, 八 巻悟郎, 渡辺一功, 池本秀雄, 小沼一郎：ケトコ ナゾールによるカンジダ症の治療. Jpn. J. Med. Mycol., 25 : 257-273, 1984.

12) Binder, R.E., Faling, L.J., Pugatch, R.D., Mahasaen, C. and Snider, G.L.: Chronic necrotizing pulmonary aspergillosis: A discreates clinical entity. Medicine, 61:109-124, 1982.

13) Meyer, R.D., Young, L.S., Armstrong, D.A. and Yu, B.: Aspergillosis complicating neoplastic disease. Am. J. Med., 54 : 6-15, 1973.

14) Mori, T., Matsumura, M., Isonuma, H., Hamamoto, T., Watanabe, K., Ikemoto, H., Ishioka, T. and Fukuda, Y.: A case of tracheal aspergillosis. Jpn. J. Med. Mycol., (in press).

15）渡辺一功：クリプトコックス症の病像と診断一内 科領域より一. Jpn. J. Med. Mycol., 22：148 $-154,1981$.

16）渡辺一功, 池本秀雄：クリプトコックス。日本臨 牀，43 (秋季臨時增刊号)：173-176, 1985.

17）條田孝子, 池田玲子, 西川朱実: 真菌症の血清学的 診断法：1.クリプトコッカス症の血清学的診断法 について.モダンメディア, 31:71-81, 1985.

18) Stamm, A.M. and Dismukes, W.E.: Cryptococcus neoformans. In Internal Medicine (Stein, H. J. ed.), p. 1439-1442, Little, Brown and Co., Boston, 1983.

19）池本秀雄, 渡辺一功, 森 健, 泉 昭, 浜本恒 男, 磯沼 弘, 小原共雄：内科領域真菌症. 日独医 
報, $20 ： 388-398,1985$.

20）渡辺一功：Phycomycosis(いわゆるムコール症)。 内科領域から一診断の問題点. Jpn. J. Med. Mycol., 19 : 101-107, 1978.

21）渡辺一功, 森 健, 浜本恒男, 磯沼 弘, 池本秀
雄：真菌性肺炎. 臨牀と研究，62：2772-2777, 1985.

22）渡辺一功：ノカルジア症. 現代医療, 16： 707-712, 1982.

\section{Opportunistic Fungus Infections -Internal Medicine- \\ Kazuyoshi Watanabe \\ Department of Internal Medicine, Juntendo University School of Medicine 2-1-1, Hongo, Bunkyo-ku, Tokyo 113, Japan}

Recently, opportunistic fungus infections with yeast and moulds have become increasingly common in patients with immunocompromised host. Candida species, Aspergillus species, Phycomycetes and Cryptococcus neoformans remain most common but other organisms are being encountered as pathogens.

With the exception of certain types of fungus disease such as candidemia, Candida esophagitis and cryptococcal meningitis, most opportunistic fungus infections are difficult to diagnose.

We report our experiences with opportunistic fungus infections at Juntendo University Hospital and present an approach for diagnosis of these diseases.

Clearly, sensitive and reliable diagnostic tools are needed. We also need more effective, less toxic drugs than are currently available and to learn how to use the available drugs as effectively as possible. 